\title{
Anti-cancer properties of Microalgae (T1) Extract in Breast Cancer Cell Lines
}

\section{Noor Alateyah, Salma Muhammad, Hanan Nazar, Allal Ouhtit}

Department of Biological and Environmental Sciences

Qatar University, Doha, Qatar

\section{ABSTRACT}

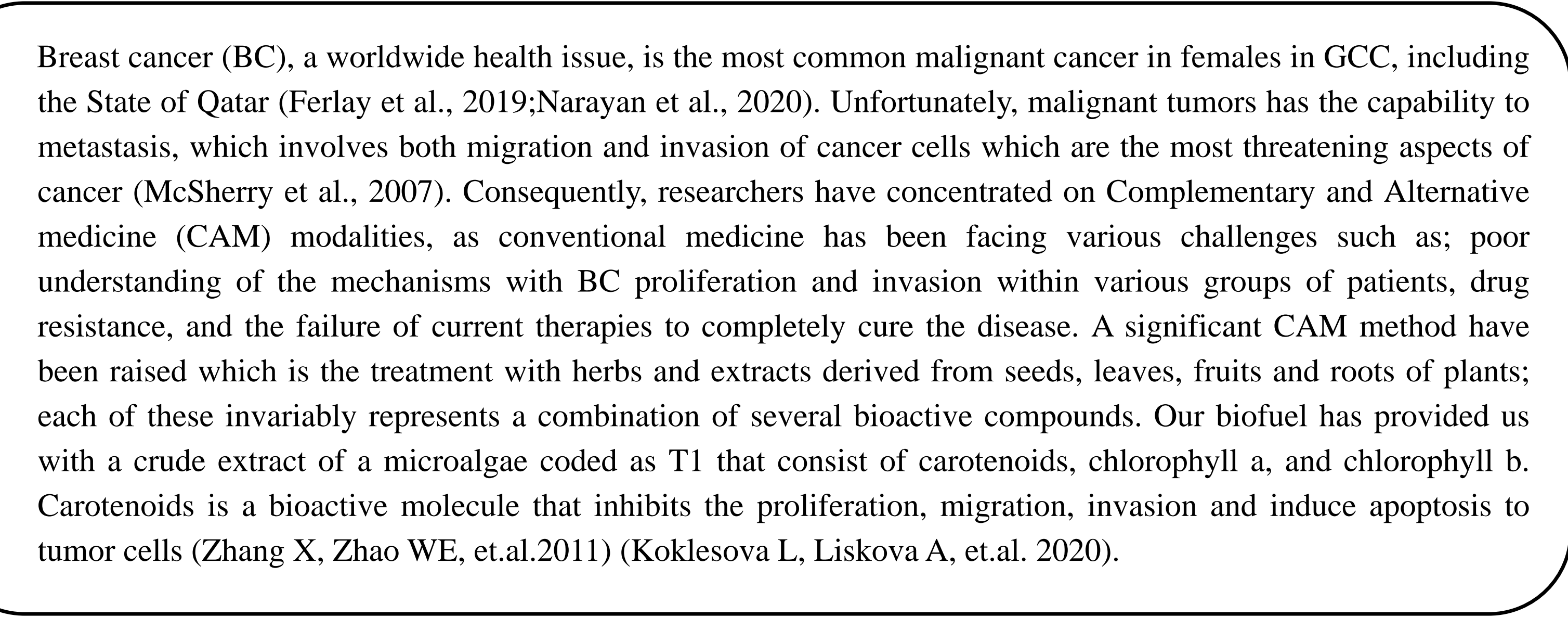

\section{OBJECTIVES}

Our present study aims to examine the effect of $\mathrm{T} 1$ extract on the proliferation, migration and invasion of MDA-MB-231 triple negative metastatic breast tumour cell line compared to the 3T3L normal cell line.

\section{METHODOLOGY}

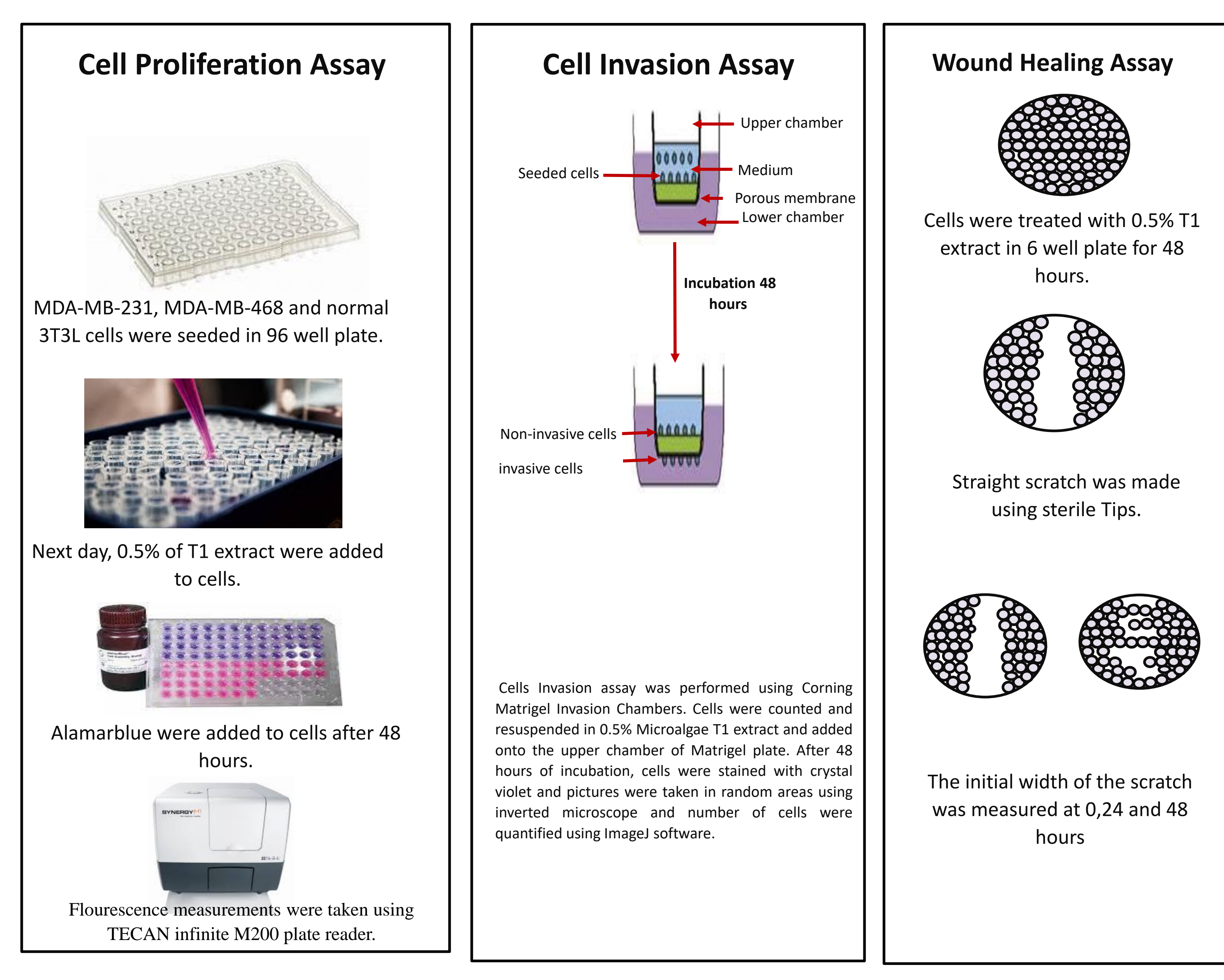

\section{RESULTS}

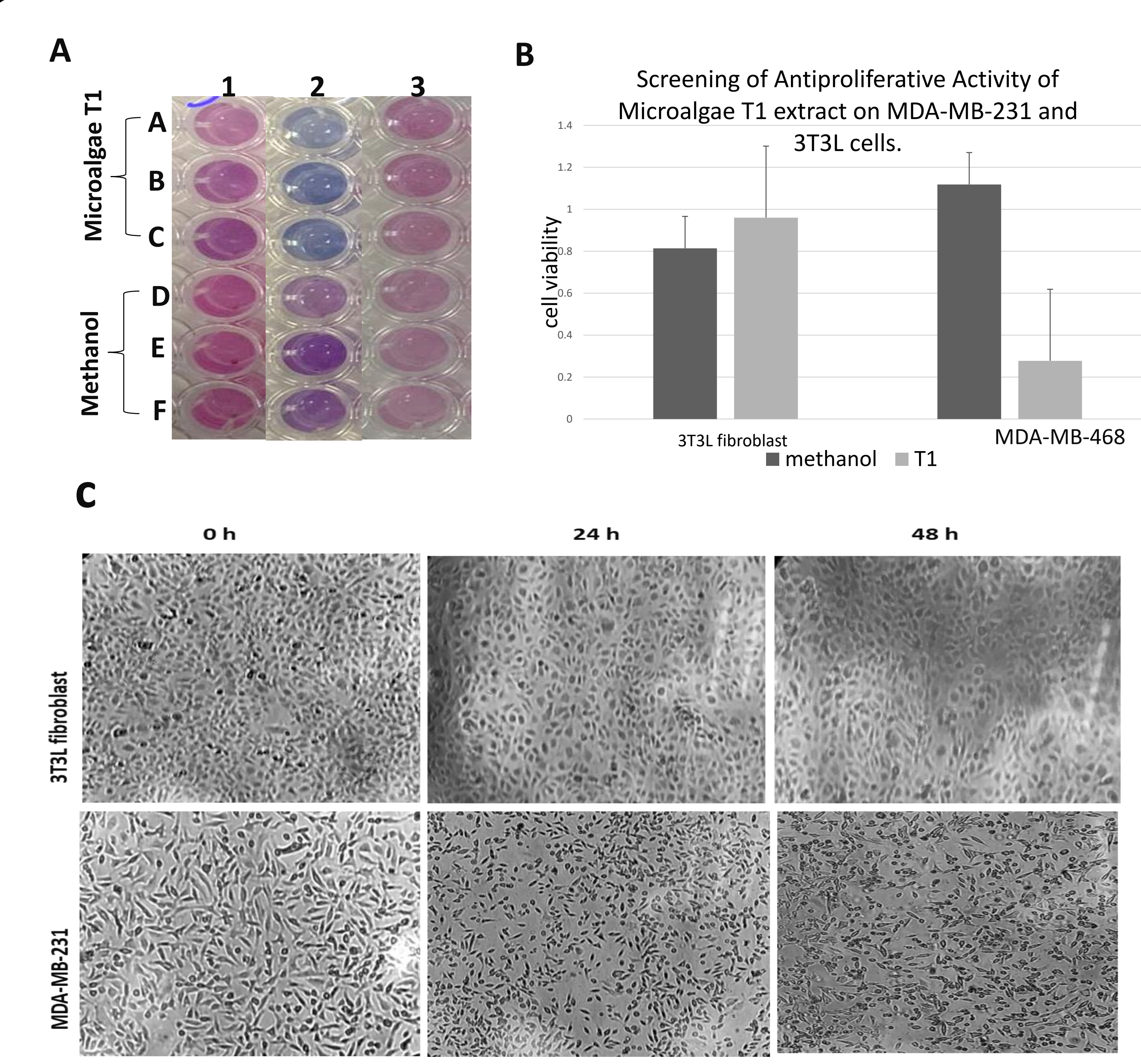

Figure1: (A) Alamar blue cell proliferation assay results of 1-MDA-MB-231,2-MDA-MB-468 breast cancer cells compared to normal
3T3L fibroblast after 48 hours of T1 extract treatment. (B) Showing the effect of T1 extract on MDA-MB-468 BC cells compared to

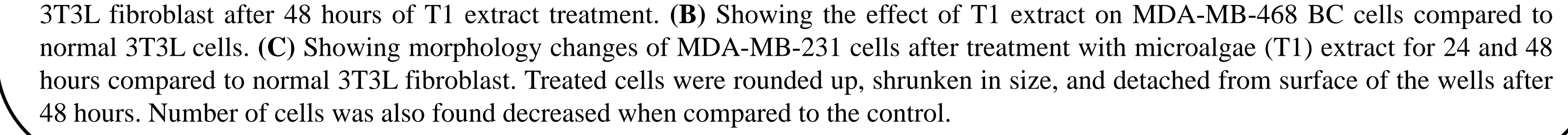

\section{RESULTS}

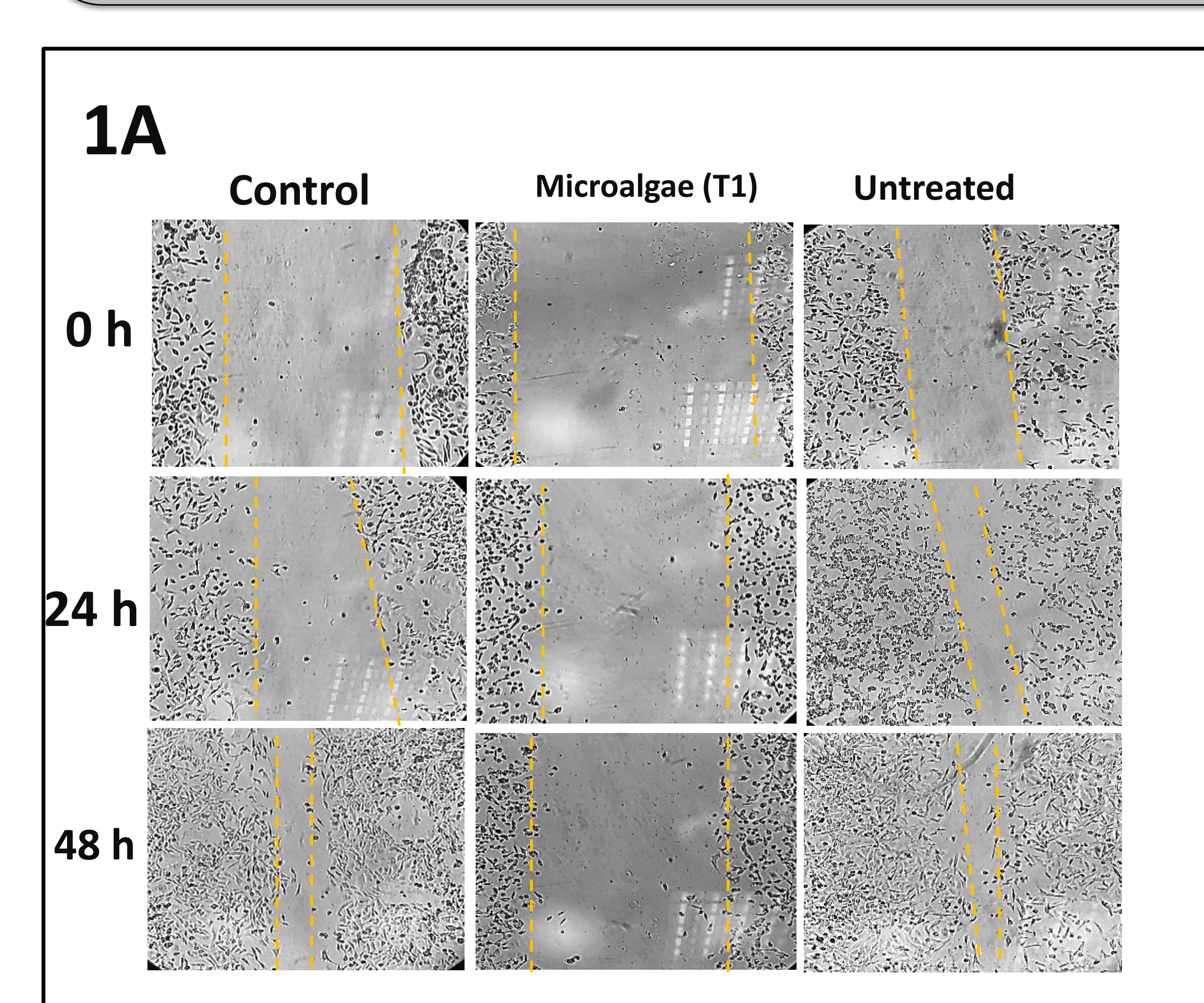

$2 \mathrm{~A}$

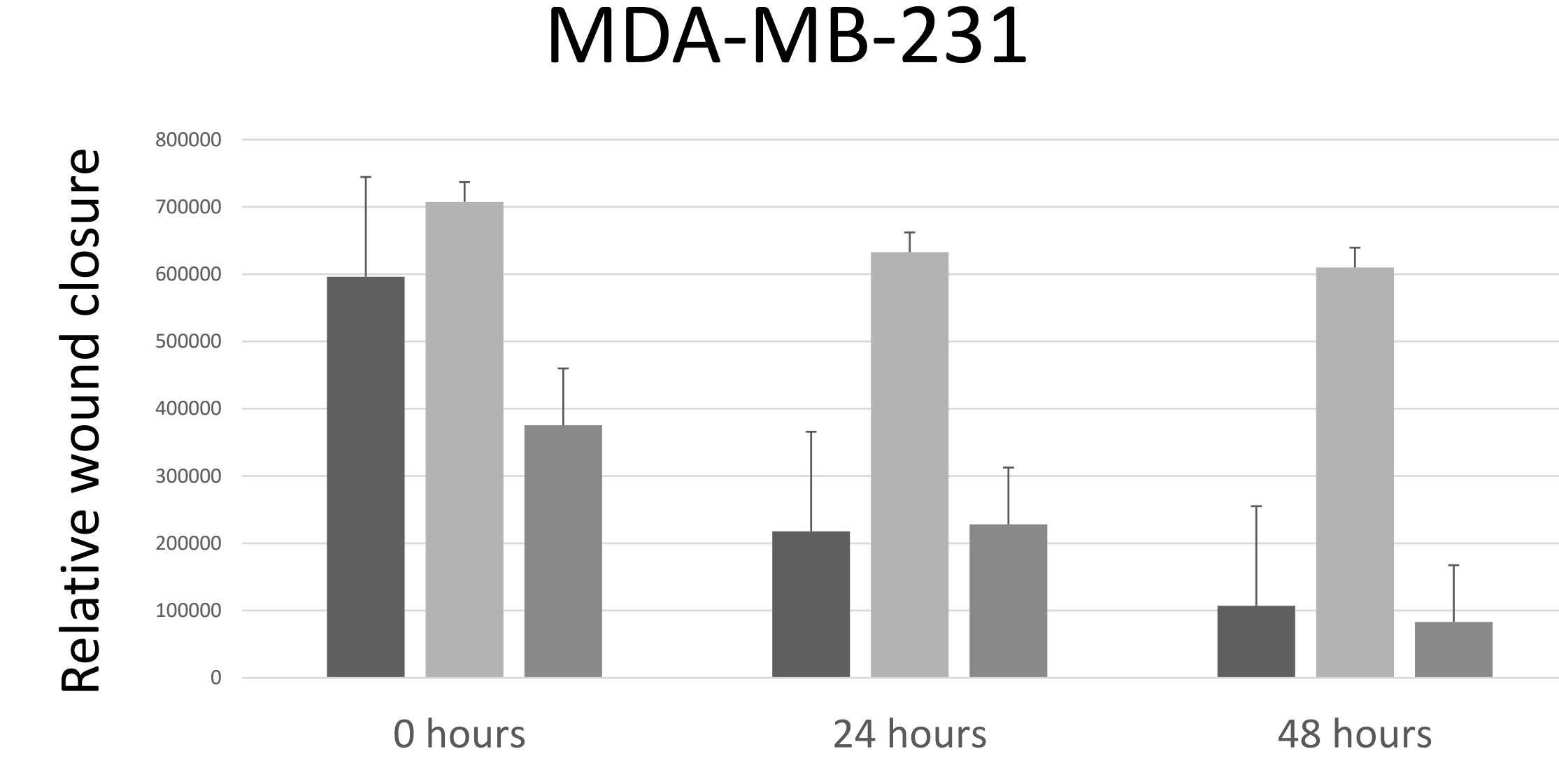

Time points

- control $\quad$ - T1 50\% $\quad$ methanol 50\%

Figure 2: Wound healing assay showing the effect of Microalgae T1 on migration of MDA-MB-231 cell line. (1A) Death of MDA-MB-231 cells caused by Microalgae T1 extract decreased cell migration compared to methanol and control. (2A) Graphical representation of the relative wound closure after treatment with $0.5 \%$ Microalgae T1 extract and 0.5\% methanol compared to control at different time points 0,24 and 48 hours.

1B

2B

MDA-MB-231
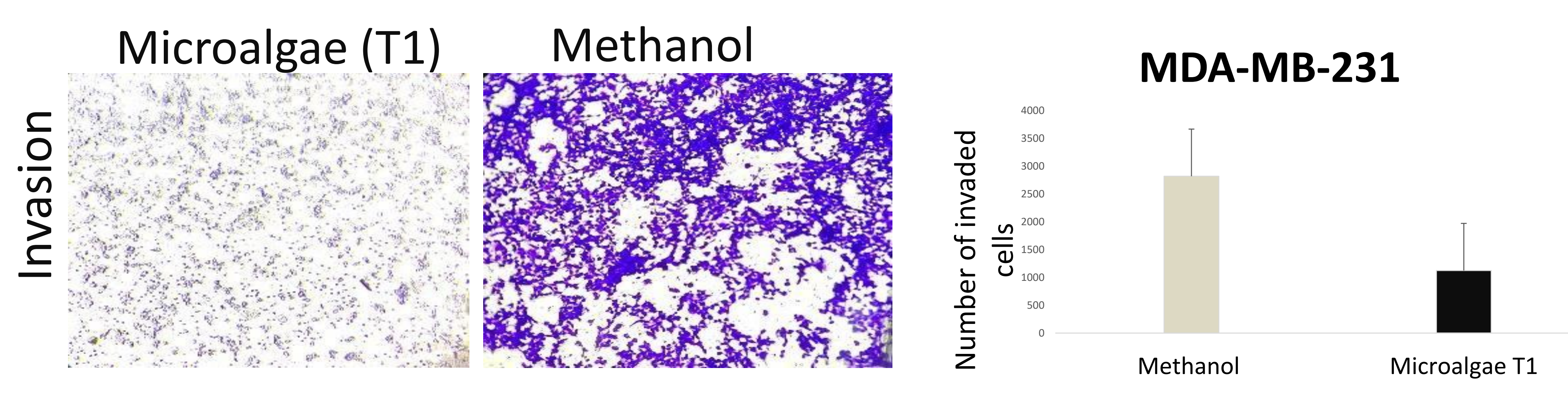

Figure 3: Microalgae extract inhibited the invasion of MDA-MB-231 cells. Boyden chamber assay was performed to assess invasion in MDA-MB-231 cells. (1B) Showing crystal violet-stained invaded cells at the lower chamber of transwell membrane after treating MDA-MB-231 cells by Microalgae T1 compared to methano (control). (2B) Data illustrates the relative cell number of treated cells compared to methanol with a minimum of three areas were randomly selected to count cells
under an inverted microscope.

\section{Discussion}

According to (Zhang X, Zhao WE, et.al.2011) carotenoids inhibit the proliferation of several cancer cell lines including breast, prostate, melanoma, lung, and leukemia, resulting in cycle-cycle arrest (Stivala LA, Savio M, et.al. 2000), inhibition of the malignant transformation of cancer cells (Bertram JS, Pung A, et.al. 1991) and the induction of apoptosis (Muto Y, Fujii J, et.al.1995). Interestingly, carotenoids act as an inhibitor to various invasive and metastatic mechanisms (Koklesova L, Liskova A, et.al. 2020). Carotenoids clearly decreased the expression of MMP-2, MMP-9, N-cadherin, CD44 receptor, and $\beta$-catenin. Similarly, it had inhibited the MAPK, NOTCH signaling, PI3K/AKT/NF-KB, Wnt pathway (Koklesova L, Liskova A, et.al. 2020). These data prove the effect of carotenoids on inhibiting proliferation, migration, invasion and inducing apoptosis at molecular level.

\section{Conclusion}

In conclusion, the microalgae (T1) extract inhibited cell proliferation and invasion of MDAMB-231 BC cell line. Ongoing experiments aim to further validate this observation in various other cancer cell lines, and reveal the underlying molecular mechanisms mediating its anticancer properties.

\section{REFERENCES}

Standardized Assessment Tool. EurJ Breast Health 16 124-128.

MCSherry EA, Donatello S, Hopkins AM \& MCDonnell S 2007 Molecular basis of invasion in breast cancer. Cell Mol Life Sci 64 3201-3218.

4. Naor D, Nedvetzki S, Golan I, Melnik L \& Faitelson Y 2002 CD44 in cancer. Crit Rev Clin Lab Sci 39 527-579.

Kollesova L, Liskova A, Samec M, Zhai K, Abotaleb M, Ashrafizadeh M, Brockmueller A, Shakibaei M, Biringer K, Bugos O, Najafi M, Golubnitschaja O, Büsselberg D, Kubatka P. Carotenoids in Cancer Metastasis-Status Quo and Outlook. Biomolecules. 2020 Dec 10;10(12):1653. doi: 10.3390/biom10121653. PMID: 33321708; PMCID: PMC7763577.

Zhang X, Zhao WE, Hu L, Zhao L, Huang J. Carotenoids inhibit proliferation and regulate expression of peroxisome proliferators-activated receptor gamma (PPARY) in K562 cancer cells. Arch Biochem Biophys. 2011 Aug 1;512(1):96-106. doi: 10.1016/j.abb.2011.05.004. Epub 2011 May 18. PMID: 21620794.

Muto Y, Fujii I, Shidoji Y, Moriwaki H, Kawaguchi T, Noda T. Growth retardation in human cervical dysplasia-derived cell lines by beta-carotene through down-regulation of epidermal growth factor receptor. Am J Clin Nutr. 1995 Dec;62(6 Suppl):1535S-1540S. doi: 10.1093/ajcn/62.6.15355. PMID: 7495256. 